\title{
Development and Validation of a web-based Postoperative Clostridioides difficile infection risk prediction model
}

Sang H. Woo ${ }^{1}$, Bryan Hess ${ }^{2}$, Lily Ackermann ${ }^{1}$, Scott W. Cowan ${ }^{3}$, Jennifer Valentine ${ }^{1}$

1 Department of Medicine- Division of Hospital Medicine, Thomas Jefferson University, Philadelphia, PA 19107

2 Department of Medicine- Division of Infectious Disease, Thomas Jefferson University, Philadelphia, PA 19107

${ }^{3}$ Department of Surgery, Thomas Jefferson University, Philadelphia, PA 19107

Running title: preoperative C. difficile risk assessment, C. difficile colitis, risk model, machine learning

\section{Correspondence:}

1. Sang Hoon Woo, M.D.: Department of Medicine, Thomas Jefferson University email: sang.woo@jefferson.edu 
medRxiv preprint doi: https://doi.org/10.1101/2020.06.23.20138420; this version posted June 24, 2020. The copyright holder for this preprint (which was not certified by peer review) is the author/funder, who has granted medRxiv a license to display the preprint in perpetuity.

\begin{abstract}
:
Background: Clostridioides difficile infection is associated with significant morbidity, mortality and increased costs. Assessment of the postoperative $C$. difficile infection risk is necessary to improve the outcome of surgical patients.
\end{abstract}

Objective: To develop and validate a risk prediction tool for $C$. difficile infection after surgery.

Methods: In this retrospective cohort study, 2,451,169 surgical patients from the American College of Surgeons National Surgical Quality Improvement Program Database (ACS-NSQIP) over 2015-2017 were included. Nine predictors were selected for the model: age, preoperative leukocytosis $\left(>12 \times 10^{9} / \mathrm{L}\right)$, hematocrit $(\leq 30 \%)$, chronic dialysis, insulin dependent diabetes, weight loss, steroid use, presence of preoperative sepsis, and surgery type. A second model included hospital length of stay as a predictor. A predictive model was developed using ACSNSQIP 2015-2016 training cohort $(n=1,435,157)$ and tested using 2017 validation cohort $(n=1,016,012)$. Multivariate logistic regression was used for the model.

Main outcome: The primary outcome was postoperative 30-day C. difficile infection (CDI).

Results: $\quad 0.39 \%$ of the patients $(n=9,675)$ developed CDI and $42.3 \%(n=4,091)$ of CDI occurred post-discharge. The Clostridioides difficile risk prediction model had excellent AUC (area under the receiver operating characteristic curve) for postoperative $C$. difficile infection (training cohort $=0.804$, test cohort $=0.803$ ). The model that includes hospital length of stay has a high AUC (training cohort $=0.841$, test cohort $=0.838$ ).

Conclusion: The $C$. difficile prediction model provides a robust predictive tool for postoperative C. difficile infection. 
medRxiv preprint doi: https://doi.org/10.1101/2020.06.23.20138420; this version posted June 24, 2020. The copyright holder for this preprint (which was not certified by peer review) is the author/funder, who has granted medRxiv a license to display the preprint in perpetuity.

\section{Background:}

Clostridioides (formerly Clostridium) difficile is a commonly identified cause of healthcareassociated infection in the United States. ${ }^{1}$ Preventive measures include improving antibiotic use, healthcare facility cleaning, patient isolation, and hand hygiene. ${ }^{2-4}$

Despite aggressive preventive measures, the clinical and economic impacts of $C$. difficile infection (CDI) remain significant and $C$. difficile maintains an "Urgent Threat" status according to the Centers for Disease Control and Prevention (CDC). ${ }^{4-6}$ There is a significant healthcare burden with C.difficile infection with increased morbidity and higher healthcare costs. ${ }^{3,6,7}$ The CDC estimated 223,900 CDI cases in hospitalized patients in 2017, with an estimated 12,800 deaths and 1 billion dollars in estimated attributable healthcare costs. ${ }^{4}$ In the same report, they noted that healthcare-associated CDI cases are decreasing, however community-associated cases are not. ${ }^{8}$

The ability to predict and target specific C.difficile infection preventive measures to the highest risk patients has important implications for hospitals. In one large cohort of postoperative patients over a four-year period, CDIs developed at a rate of $0.4 \%$ per year, with a 12 -fold increase in morbidity and 5-fold increase in mortality associated with CDI compared to post-op patients without CDI. ${ }^{9}$ It was reported that over $8 \%$ of admitted patients are carriers of $C$. difficile with high risk of infection. ${ }^{10}$ Surgical patients are at particularly high risk for CDI. Extended antimicrobial prophylaxis given to reduce surgical site infection is associated with increased $C$. difficile infection. ${ }^{11,12}$ There is also decreased throughput in hospitals and decreased availability of beds as CDIs necessitate a need for isolation and effective terminal cleaning processes. The Centers for Medicare and Medicaid Services uses hospital-acquired CDI rates as part of their reimbursement to hospitals and the financial penalties for institutions failing to meet quality metric 
standards are significant. ${ }^{13}$ Even though $C$. difficile infection has been associated with significant morbidity and mortality $6,14,15$, to our knowledge, a practical risk model for postoperative CDI based on a large number of patients and hospitals is not available. Oh et al. demonstrated a machine learning algorithm to predict the risk of CDI but it was trained on patients from only two hospitals. Additionally, its use of over 4000 variables limits ease of use in clinical settings and the model is not specific to surgical patients. ${ }^{16}$ Other studies showed predictive models for recurrent CDI with variable discrimination, but these were not for initial CDI infection prediction and not limited to surgical patients. ${ }^{17,18}$

Our study was conducted using the database from the American College of Surgeon's National Surgical Quality Improvement Program (ACS-NSQIP). ACS-NSQIP clinical data are collected from more than 500 US hospitals and includes preoperative clinical features, risk factors, and 30 day postoperative outcomes. ${ }^{19-21}$

\section{Methods:}

\section{Study population}

Data from 2015 to 2017 ACS-NSQIP database were used for the analysis. 2,451,169 participants were included in the study cohort. Study participants flow chart is shown in eFigure I in the Supplement. Clinical data and occurrences of complications were collected by trained surgical clinical reviewers at each participating hospital and participants were followed for 30 days after surgery. Analyzed risk factors included age, sex, smoking, history of congestive heart failure, history of chronic obstructive pulmonary disease, diabetes, presence of preoperative sepsis, use of 
hypertension medications, steroid use, admission origin, ascites, chronic dialysis, bleeding disorder, disseminated cancer, dyspnea, emergency surgery, preoperative renal failure, weight loss, American Society of Anesthesiologists' class, and preoperative functional status. Preoperative laboratory tests in the analysis include serum sodium, creatinine, white blood cell count, and hematocrit.

\section{Outcome}

The primary outcome was the occurrence of 30-day postoperative Clostridioides difficile infection. In the NSQIP, the diagnosis of CDI is met by one of two criteria: "documentation in the medical record of a positive $C$. difficile test result in the 30 day postoperative period, or documentation that the patient is receiving current treatment for C. difficile". ${ }^{22,23}$

\section{Data Analysis}

2,451,169 patients from 2015-2017 were included in the initial analysis. Patient demographic factors were assessed using Pearson $\chi^{2}$ for categorical variables and Wilcoxon for continuous variables.

Our $C$. difficile predictive model was trained using data from years 2015 and $2016(\mathrm{~N}=1,435,157)$ and the model was tested using data from $2017(\mathrm{~N}=1,016,012)$. Model predictors were chosen based on a backward elimination method and clinical importance. Multivariate logistic regression analysis was done to obtain predictor coefficient, standard error, and adjusted Odds ratio. 
medRxiv preprint doi: https://doi.org/10.1101/2020.06.23.20138420; this version posted June 24,2020 . The copyright holder for this preprint (which was not certified by peer review) is the author/funder, who has granted medRxiv a license to display the preprint in perpetuity.

All rights reserved. No reuse allowed without permission.

GridSearchCV package with 5-fold cross validation was used to select the model parameters. We used AUC (Area Under the Curve) to evaluate the performance of a model. Separate categories were made for missing values of laboratory concentrations (serum hematocrit, white blood cell count and creatinine). Flow diagram of the study cohort is in the online Supplement Figure I. Python (version 3.6.6), Statsmodels (version 0.9.0), r programming (RStudio version 1.1.463) were used for statistical analysis. Scikit-learn package was utilized for machine learning modeling and a web-based risk model. The Thomas Jefferson University institutional review board approved this study and waived informed consent from study participants.

\section{Results}

Table 1. Characteristics of the patients (patients from 2015-16)

\begin{tabular}{|c|c|c|c|}
\hline & $\begin{array}{c}\text { No C. difficile } \\
\text { Infection } \\
(\mathrm{n}=1,429,062)\end{array}$ & $\begin{array}{c}\text { C. difficile infection } \\
(\mathrm{n}=6,095)\end{array}$ & p-value \\
\hline Age (Mean \pm SD) & $56.5 \pm 16.8$ & $64.6 \pm 15.7$ & $*$ \\
\hline Sex (Male) & 43.36 & 45.96 & $*$ \\
\hline Preoperative sepsis- None(\%) & 94.65 & 79.34 & $*$ \\
\hline Preoperative SIRS(\%) & 2.93 & 8.42 & $*$ \\
\hline Preoperative Sepsis(\%) & 2.05 & 9.14 & $*$ \\
\hline Preoperative Septic Shock(\%) & 0.36 & 3.1 & $*$ \\
\hline
\end{tabular}


medRxiv preprint doi: https://doi.org/10.1101/2020.06.23.20138420; this version posted June 24, 2020. The copyright holder for this preprint (which was not certified by peer review) is the author/funder, who has granted medRxiv a license to display the preprint in perpetuity.

\begin{tabular}{|c|c|c|c|}
\hline No diabetes(\%) & 84.42 & 78.87 & * \\
\hline Non-Insulin dependent diabetes(\%) & 9.82 & 9.12 & * \\
\hline Diabetes - Insulin dependent $(\%)$ & 5.76 & 12.01 & $*$ \\
\hline $\begin{array}{c}\text { Hypertensive } \\
\text { medication use(\%) }\end{array}$ & 44.78 & 59.44 & $*$ \\
\hline Ascites(\%) & 0.31 & 1.76 & * \\
\hline Weight Loss $(\%)$ & 1.18 & 5.35 & * \\
\hline Emergency surgery(\%) & 8.84 & 21.2 & $*$ \\
\hline $\operatorname{COPD}(\%)$ & 4.39 & 9.94 & * \\
\hline Congestive Heart Failure(\%) & 0.87 & 3.43 & $*$ \\
\hline Disseminated cancer(\%) & 2.26 & 6.43 & $*$ \\
\hline Smoker(\%) & 17.64 & 20.34 & $*$ \\
\hline Preoperative renal failure(\%) & 0.34 & 2.18 & $*$ \\
\hline Chronic dialysis $(\%)$ & 1.28 & 5.07 & $*$ \\
\hline Steroid use $(\%)$ & 3.59 & 8.11 & $*$ \\
\hline Bleeding disorder(\%) & 4.04 & 11.88 & $*$ \\
\hline ASA Class 1-No Disturb(\%) & 8.74 & 2.13 & $*$ \\
\hline 2-Mild Disturb(\%) & 44.8 & 21.2 & * \\
\hline
\end{tabular}




\begin{tabular}{|c|c|c|c|}
\hline 3-Severe Disturb(\%) & 40.38 & 54.82 & $*$ \\
\hline 4-Life Threatening(\%) & 5.9 & 20.75 & $*$ \\
\hline 5-Moribund(\%) & 0.17 & 1.1 & $*$ \\
\hline Preoperative WBC $(\times 10 \% / \mathrm{L})$ & 8.15 & 9.76 & $*$ \\
\hline Preoperative Hematocrit(\%) & 39.73 & 36.37 & $*$ \\
\hline Preoperative Sodium(mEq/L) & 139.08 & 138.25 & $*$ \\
\hline Preoperative Creatinine(mg/dL) & 1.00 & & $* 30$ \\
\hline
\end{tabular}

$* \mathrm{P}<0.001$

\section{Results:}

\section{Participant Characteristics}

The study included 2,451,169 participants from 2015-2017 cohort and 56.8\% were women. The overall 30-day post-operative $C$. difficile infection incidence was $0.39 \%(\mathrm{n}=9,675)$.

Table 1 shows demographic characteristics of study participant cohorts from 2015-16. CDI rate was $0.42 \%(\mathrm{n}=6,095)$. Patients who developed $C$. difficile infection were older (64.6 vs 56.5 , $\mathrm{p}<0.001)$ and had a higher rate of insulin dependent diabetes $(12.0 \%$ vs $5.8 \%, \mathrm{p}<0.001)$. More Patients with C. difficile infection had disseminated cancer, COPD, and $\operatorname{ESRD}(\mathrm{p}<0.001)$. 
medRxiv preprint doi: https://doi.org/10.1101/2020.06.23.20138420; this version posted June 24, 2020. The copyright holder for this preprint (which was not certified by peer review) is the author/funder, who has granted medRxiv a license to display the preprint in perpetuity.

All rights reserved. No reuse allowed without permission.

\section{Postoperative 30-day mortality and readmission}

Figure 1 illustrates 30-day unadjusted mortality and readmission rates with postoperative $C$. difficile infection from 2015 to 2017. Patients who developed postoperative CDI had a high 30day mortality rate $(5.7 \%$ vs $0.9 \%)$. 30-day Readmission rates with CDI were also significantly higher $(32.5 \%$ vs $5.1 \%)$.

Figure 1. Unadjusted 30-day postoperative mortality and readmission rates associated with C. difficile infection
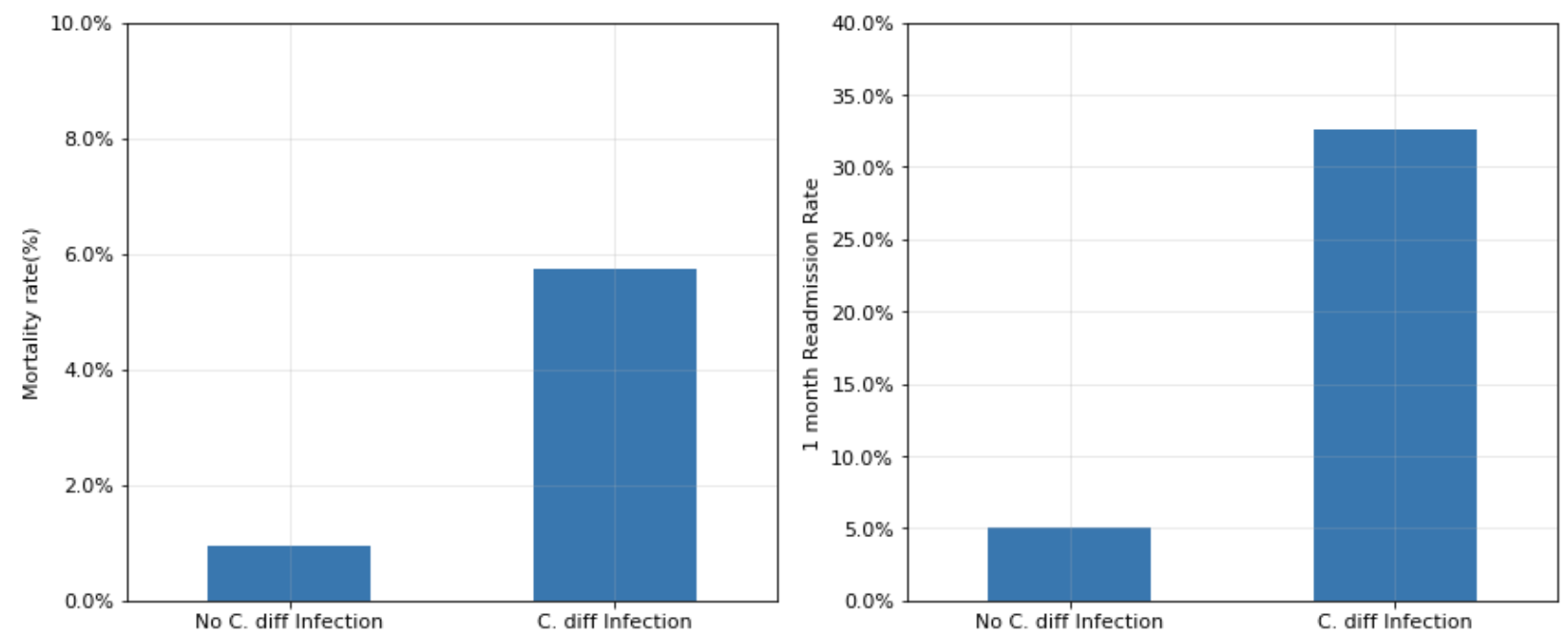

Age, leukocytosis, anemia, length of stay and incidence of $C$. difficile infection

Figure 2 shows the unadjusted rates of postoperative $C$. difficile infection with age, preoperative leukocytosis (white blood cell count $>12 \times 10^{9} / \mathrm{L}$ ), preoperative anemia (hematocrit $\leq 30 \%$ ) and 9 
medRxiv preprint doi: https://doi.org/10.1101/2020.06.23.20138420; this version posted June 24, 2020. The copyright holder for this preprint (which was not certified by peer review) is the author/funder, who has granted medRxiv a license to display the preprint in perpetuity.

All rights reserved. No reuse allowed without permission.

hospital length of stay from 2015-17 cohort. The incidence of infection increased with older age. Preoperative leukocytosis $(0.9 \%$ vs $0.4 \%)$ and anemia $(1.6 \%$ vs $0.4 \%)$ were significantly associated with CDI. Longer hospital length of stay also had significant association with the incidence of $C$. difficile infection ( $>10$ days: $2.9 \%, 6-10$ days: $1.1 \%, 0-5$ days $0.2 \%$ ).

Figure 2. Age, Leukocytosis, Anemia and Hospital Length of Stay and C. difficile infection
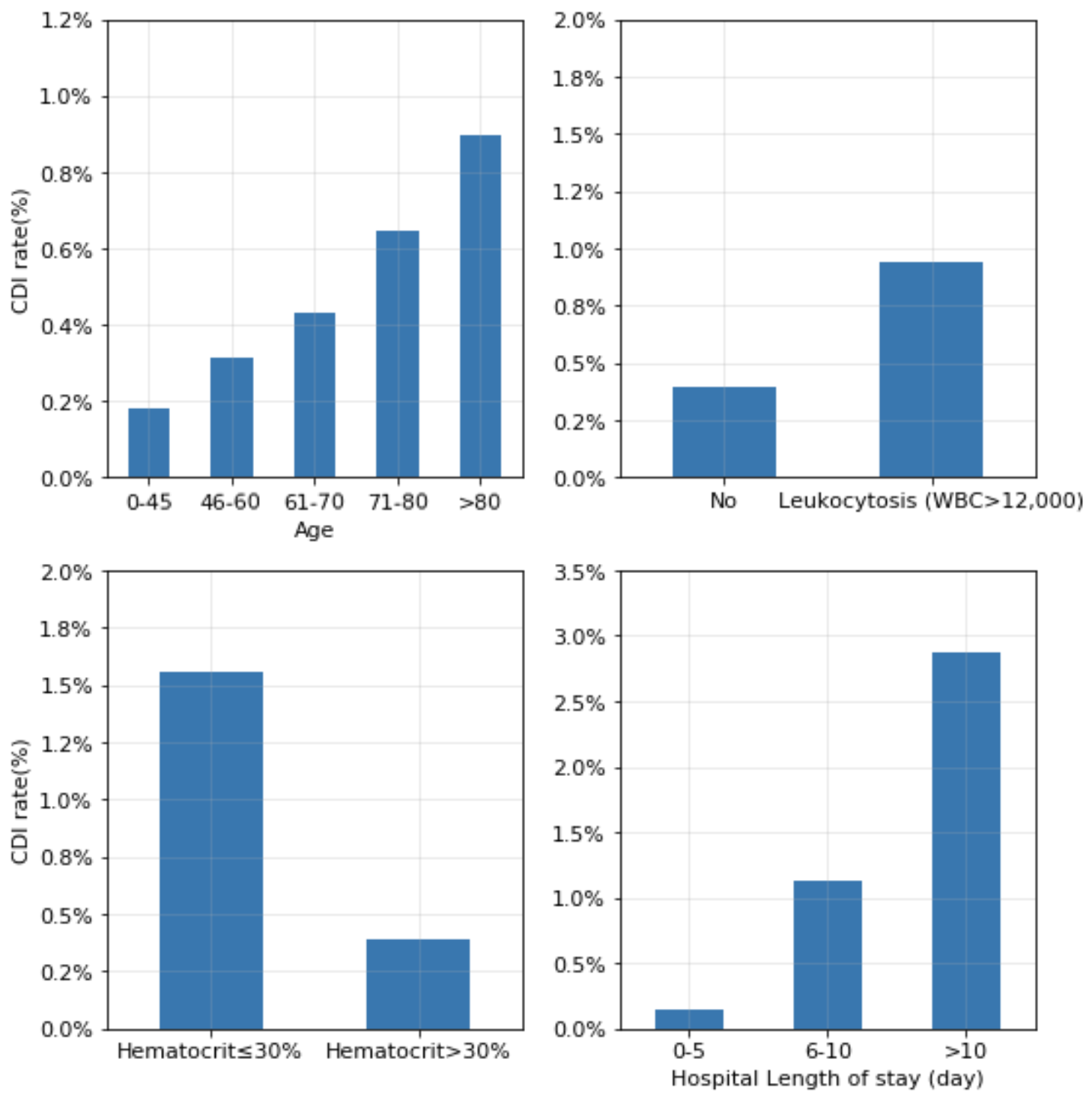
medRxiv preprint doi: https://doi.org/10.1101/2020.06.23.20138420; this version posted June 24, 2020. The copyright holder for this preprint (which was not certified by peer review) is the author/funder, who has granted medRxiv a license to display the preprint in perpetuity.

All rights reserved. No reuse allowed without permission.

\section{Surgery type and $C$. difficile infection}

There is a significant difference in the $C$. difficile infection rates between the types of surgery.

Figure 3 shows unadjusted CDI rate according to the type of surgery from the 2015-17 cohort.

Intestinal surgery $(1.56 \%)$, aorta vascular surgery $(1.41 \%)$, and liver-pancreas surgery $(1.34 \%)$ demonstrated particularly high rates of CDI. Thyroid surgery $(0.05 \%)$ and orthopedic upper extremity $(0.06 \%)$ demonstrated lower rates of CDI.

Figure 3. 30-day postoperative $C$. difficile infection occurrences (\%) according to surgery

type

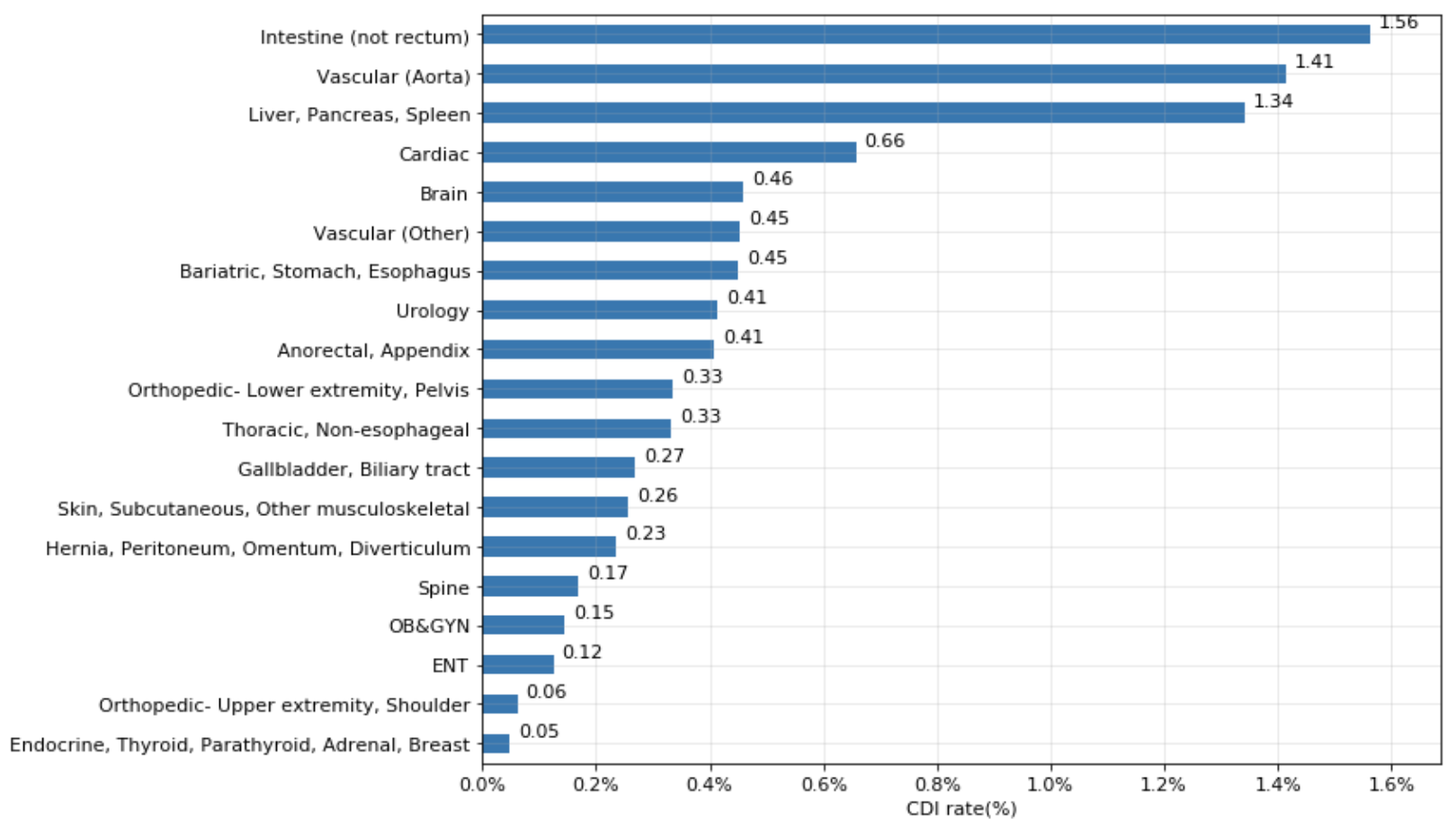


medRxiv preprint doi: https://doi.org/10.1101/2020.06.23.20138420; this version posted June 24, 2020. The copyright holder for this preprint (which was not certified by peer review) is the author/funder, who has granted medRxiv a license to display the preprint in perpetuity.

\section{Prediction and validation of 30 day postoperative $C$. difficile infection}

Table 2 shows nine predictors of postoperative $C$. difficile infection. Age, preoperative leukocytosis (white blood cell count $>12 \times 10^{9} / \mathrm{L}$ ), preoperative anemia (hematocrit $\leq 30 \%$ ), chronic dialysis, preoperative sepsis, chronic corticosteroid use, and weight loss $(>10 \%$ body weight loss in last 6 months) were significantly associated with CDI. Insulin dependent diabetes mellitus was also significant similar to a previous study. ${ }^{24}$ Preoperative SIRS (Odds ratio (OR)=1.89, $\mathrm{p}<0.001)$, sepsis $(\mathrm{OR}=2.16, \mathrm{p}<0.001)$, and septic shock $(\mathrm{OR}=2.25, \mathrm{p}<0.001)$ were strongly associated with $C$. difficile infection. The model built with the training cohort was validated on the testing cohort of 1,016,012 patients from 2017. eFigure II in the Supplement shows excellent calibration, well matched with the 45-degree line.

The risk model has excellent AUC (train cohort $=0.804$, test cohort $=0.803$ ).

Table 2. Adjusted odds ratio (OR) of $C$. difficile infection predictors

\begin{tabular}{|c|c|c|c|c|}
\hline & Odds ratio (95\% CI) & Coefficient & SE & P-Value \\
\hline Intercept & & -7.655 & 0.207 & $<0.001$ \\
\hline Age & $1.02(1.02-1.03)$ & 0.023 & 0.001 & $<0.001$ \\
\hline Steroid use & $1.43(1.3-1.57)$ & 0.356 & 0.048 & $<0.001$ \\
\hline Weight Loss & $1.61(1.43-1.80)$ & 0.473 & 0.060 & $<0.001$ \\
\hline Diabetes - Insulin dependent & $1.42(1.31-1.54)$ & 0.349 & 0.042 & $<0.001$ \\
\hline
\end{tabular}




\begin{tabular}{|c|c|c|c|c|}
\hline Chronic Dialysis & $2.08(1.83-2.36)$ & 0.732 & 0.064 & $<0.001$ \\
\hline $\begin{array}{l}\text { Preoperative Leukocytosis } \\
\qquad\left(\mathrm{WBC}>12 \times 10^{9} / \mathrm{L}\right)\end{array}$ & $1.37(1.26-1.47)$ & 0.311 & 0.039 & $<0.001$ \\
\hline Preoperative Hematocrit $\leq 30 \%$ & $1.95(1.81-2.09)$ & 0.667 & 0.037 & $<0.001$ \\
\hline \multicolumn{5}{|l|}{$\begin{array}{l}\text { Preoperative Sepsis } \\
\quad(\text { reference }=\text { No })\end{array}$} \\
\hline SIRS & $1.89(1.71-2.09)$ & 0.636 & 0.052 & $<0.001$ \\
\hline Sepsis & $2.16(1.95-2.4)$ & 0.772 & 0.053 & $<0.001$ \\
\hline Septic Shock & $2.25(1.92-2.65)$ & 0.813 & 0.082 & $<0.001$ \\
\hline \multicolumn{5}{|l|}{ Surgery type $($ reference $=\mathrm{ENT})$} \\
\hline anorectal, appendix & $1.86(1.23-2.80)$ & 0.620 & 0.209 & 0.003 \\
\hline bariatric, stomach, esophagus & $2.59(1.72-3.9)$ & 0.951 & 0.209 & $<0.001$ \\
\hline brain & $2.18(1.39-3.42)$ & 0.778 & 0.230 & 0.001 \\
\hline cardiac & $2.44(1.48-4.02)$ & 0.892 & 0.254 & $<0.001$ \\
\hline $\begin{array}{c}\text { endocrine, thyroid, parathyroid, } \\
\text { adrenal, breast }\end{array}$ & $0.3(0.19-0.47)$ & -1.211 & 0.237 & $<0.001$ \\
\hline gallbladder, biliary tract & $1.35(0.9-2.05)$ & 0.302 & 0.211 & 0.152 \\
\hline $\begin{array}{c}\text { hernia, peritoneum, omentum, } \\
\text { diverticulum }\end{array}$ & $1.33(0.89-1.99)$ & 0.284 & 0.207 & 0.169 \\
\hline intestine (not rectum) & $5.31(3.57-7.9)$ & 1.670 & 0.203 & $<0.001$ \\
\hline liver, pancreas, spleen & $6.0(3.99-9.01)$ & 1.791 & 0.208 & $<0.001$ \\
\hline
\end{tabular}




\begin{tabular}{|c|c|c|c|c|}
\hline obgyn & $0.99(0.65-1.5)$ & -0.015 & 0.214 & 0.944 \\
\hline $\begin{array}{c}\text { orthopedic lower extremity, } \\
\text { pelvis }\end{array}$ & $1.3(0.87-1.94)$ & 0.261 & 0.204 & 0.202 \\
\hline $\begin{array}{c}\text { orthopedic upper extremity, } \\
\text { shoulder }\end{array}$ & $0.38(0.22-0.68)$ & -0.960 & 0.289 & 0.001 \\
\hline $\begin{array}{c}\text { skin, subcutaneous, other } \\
\text { musculoskeletal }\end{array}$ & $1.57(1.04-2.37)$ & 0.453 & 0.209 & 0.030 \\
\hline spine & $0.87(0.57-1.34)$ & -0.135 & 0.217 & 0.533 \\
\hline thoracic, non-esophageal & $1.17(0.72-1.9)$ & 0.155 & 0.248 & 0.530 \\
\hline urology & $1.76(1.17-2.66)$ & 0.568 & 0.209 & 0.006 \\
\hline aorta & $4.79(2.95-7.79)$ & 1.567 & 0.248 & $<0.001$ \\
\hline vascular & $1.6(1.06-2.41)$ & 0.470 & 0.208 & 0.024 \\
\hline
\end{tabular}

* Weight loss: defined as $>10 \%$ loss body weight in last 6 months

Inclusion of hospital length of stay as a predictor for postoperative $C$. difficile infection

eTable I in the Supplement shows 10 predictors for $C$. difficile infection including hospital length of stay. The hospital length of stay is significantly associated with $C$. difficile infection with $\mathrm{P}<0.001$. The $C$. difficile risk model with 10 predictors including hospital length of stay had high predictive power (training cohort $=0.841$, testing cohort $=0.838$ ). 
Figure 4. Distribution of hospital days from surgery until CDI complication

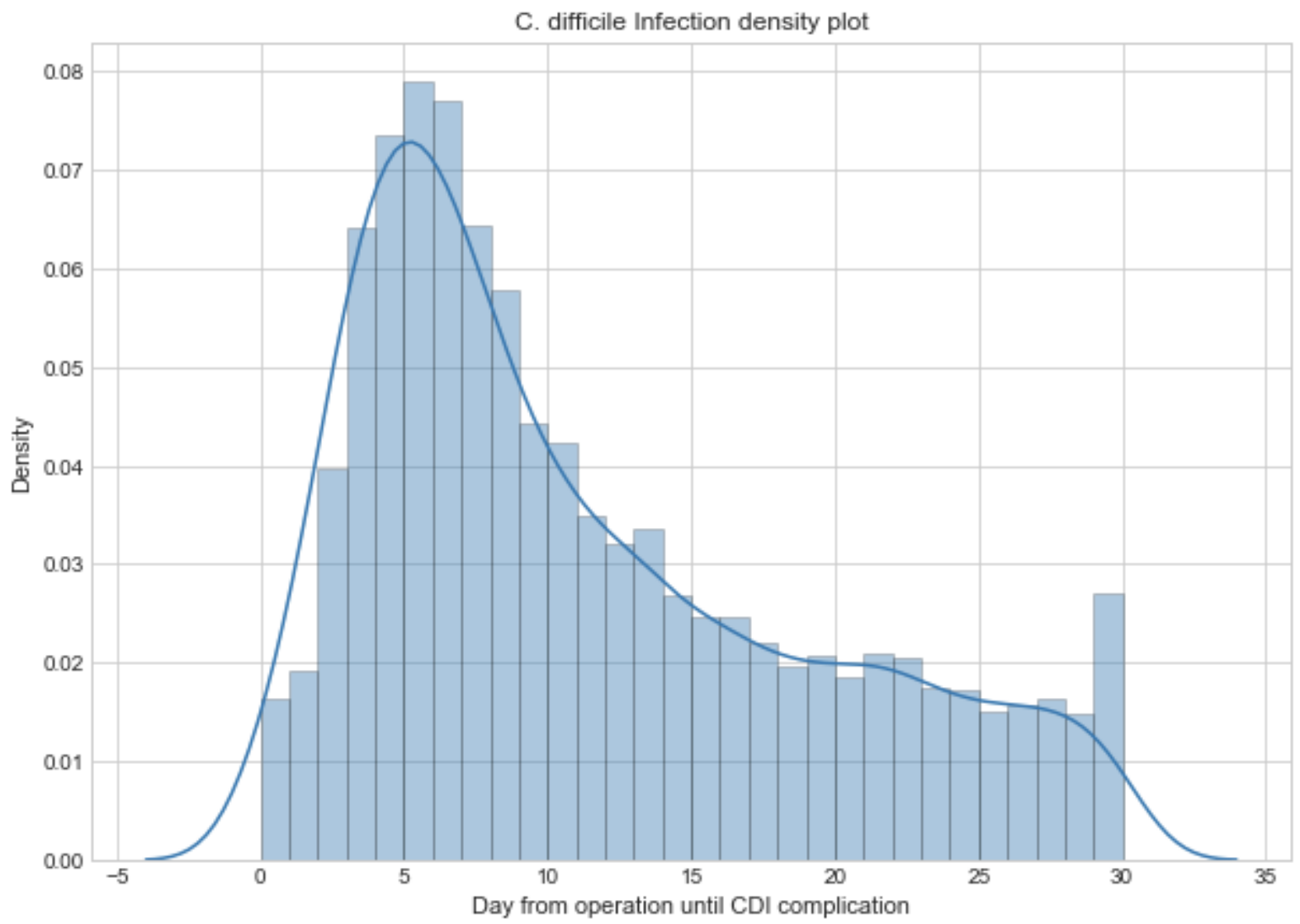

\section{Application of Postoperative $C$. difficile infection risk calculator}

The probability of the occurrence of 30-day postoperative $C$. difficile infection is calculated using intercept and coefficients from table 2 . The probability of case 3 was calculated using intercept and coefficients from Table $I$ in the supplement. The model is available at 
http://cdiffrisk.herokuapp.com/. The web-based model was built using the Scikit-learn machine learning library (eFigure 3 in the Supplement). ${ }^{25}$

$<$ case 1>

60 year old male with a history of insulin dependent diabetes, ESRD (end stage renal disease) on dialysis, weight loss $>10 \%$ in last 6 months, hematocrit $27 \%$, leukocytosis (WBC $13 \times 10^{9} / \mathrm{L}$ ), preoperative sepsis scheduled for hip surgery: 30-day postoperative $C$. difficile infection risk$5.79 \%$.

$<$ case $2>$

60 year old female with a history of insulin dependent diabetes, no weight loss, no ESRD, no steroid, hematocrit 33\%, no leukocytosis (WBC $8 \times 10^{9} / \mathrm{L}$ ), no preoperative sepsis scheduled for hip surgery: 30 day postoperative $C$. difficile infection risk: $0.36 \%$

As shown in these examples, the risk of postoperative $C$. difficile infection changes depending on comorbid conditions.

\section{Hospital day of CDI occurrences after surgery}

The distribution of hospital days in which patients developed C. difficile infection is shown in Figure 4. Median hospital day of CDI occurrence was 9 days after surgery. $42.3 \%(\mathrm{~N}=4,091$ out of 9,671) of CDI occurred post-discharge from 2015-2017 cohort. $73.5 \%$ of patients who developed CDI during the hospital admission were discharged to home, $16.8 \%$ went to a skilled care facility, and $6.5 \%$ to a rehabilitation facility. 


\section{Discussion}

Our study demonstrated that postoperative $C$. difficile infection was associated with high 30-day mortality and readmission rates similar to other studies. ${ }^{22}$ Even though many hospitals have implemented measures to reduce $C$. difficile infection, the incidence of CDI remains high, thus novel approaches are needed to prevent this serious complication. In this large cohort study, we demonstrated a $C$. difficile prediction model which was developed and validated on over 2.4 million surgical patients from year 2015-2017. By accurately assessing postoperative risk of $C$. difficile infection, this risk assessment tool enables clinicians to apply different preventive measures according to the risk level. As was shown in this study, the risk of $C$. difficile infection increased with longer length of stay, therefore different preventive methods may need to be applied if patients' hospitalization is longer than expected. Longer hospital length of stay likely increases the exposure to $C$. difficile spores. ${ }^{26,27}$ Advanced age, weight loss, steroid use for chronic conditions and diabetes are related to impaired immune status, thus increasing the risk of CDI. ${ }^{26,28}$

For patients with moderate to high risk of postoperative $C$. difficile infection, screening for $C$. difficile colonization and preventive isolation measures could be considered. Cleaning of patient rooms with ultraviolet disinfectant light may be useful. ${ }^{29}$ Minimizing the use of proton pump inhibitors and unnecessary antibiotic exposure may help reduce the rate of CDI occurrence. ${ }^{30,31}$ With a very high probability of postoperative $C$. difficile infection, the use of prophylactic probiotics and prophylactic antibiotics such as metronidazole or oral vancomycin could be a potential preventive measure, but these preventive strategies require further study to assess their efficacy and safety ${ }^{32}$. 
medRxiv preprint doi: https://doi.org/10.1101/2020.06.23.20138420; this version posted June 24, 2020. The copyright holder for this preprint (which was not certified by peer review) is the author/funder, who has granted medRxiv a license to display the preprint in perpetuity.

All rights reserved. No reuse allowed without permission.

Our study is consistent with other studies which showed that preoperative infection and sepsis are associated with increased risk of $C$. difficile infection. ${ }^{22} 14,33$

Previous studies showed a high incidence of CDI after appendectomy. ${ }^{34}$ Our study showed that intestinal, vascular, liver, cardiac and stomach surgeries have higher rates of CDI than appendectomy. The disruption of normally protective colonic microflora layer with a procedure, nasogastric tube, enemas likely contributed to the high rate of CDI with intestinal and other gastrointestinal surgeries. ${ }^{26}$

Our study also showed that a significant proportion (42.3\%) of CDI occurred after hospital discharge. The most common discharge destinations of patients who developed CDI postdischarge were home $(73.5 \%)$, followed by skilled care $(16.8 \%)$ and rehabilitation facilities $(6.5 \%)$.

Major strengths of our study: First, the model was built and validated across broad surgery types on over 2.4 million patients over three years. Second, the model was built from a cohort of national and international patients, so the model is more generalizable compared with models built from a small number of hospitals.

Limitations of our study: First, a history of prior $C$. difficile infection, recent exposure to antibiotics (including the use of perioperative antibiotics), and acid suppression therapy prior to surgery are important risk factors for $C$. difficile infection, $9,15,35,36$ however our model did not include these factors because these were not parts of ACS-NSQIP database. ${ }^{31,37}$ Second, variations of $C$. difficile infection testing among hospitals may impact testing results. ${ }^{38}$ There is also an unknown correlation between hospital length of stay and CDI rate. Further analysis is 
medRxiv preprint doi: https://doi.org/10.1101/2020.06.23.20138420; this version posted June 24, 2020. The copyright holder for this preprint (which was not certified by peer review) is the author/funder, who has granted medRxiv a license to display the preprint in perpetuity.

All rights reserved. No reuse allowed without permission.

needed to determine if a longer length of stay due to preoperative clinical factors led to a higher CDI rate or if this was secondary to longer exposure to pathogens and antibiotics.

\section{Conclusions}

In conclusion, we developed and validated a clinically useful web-based predictive model for postoperative $C$. difficile infection. Our model enables clinicians to identify patients at high risk for $C$. difficile infection to implement individualized preventive measures. Patients with CDI were older, had more preoperative comorbidities such as disseminated cancer, COPD, ESRD, and insulin dependent diabetes. Independent risk factors included anemia, leukocytosis and SIRS, weight loss, intestinal surgery, aorta vascular surgery, liver-pancreas surgery, and longer length of stay. Further research is necessary to investigate the application of this risk model in clinical settings and revise current approaches to the prevention of postoperative $C$. difficile infection.

\section{$\underline{\text { Acknowledgments }}$}

Dr. Woo had full access to all the data in the study and takes responsibility for the integrity of the data and the accuracy of the data analysis.

Funding/Support: no funding

The American College of Surgeons National Surgical Quality Improvement Program and the hospitals participating in the ACS NSQIP are the source of the data used herein; they have not 
medRxiv preprint doi: https://doi.org/10.1101/2020.06.23.20138420; this version posted June 24, 2020. The copyright holder for this preprint (which was not certified by peer review) is the author/funder, who has granted medRxiv a license to display the preprint in perpetuity.

All rights reserved. No reuse allowed without permission.

verified and are not responsible for the statistical validity of the data analysis or the conclusions derived by the authors.

\section{Disclosures:}

None

Bibliography

1. Miller BA, Chen LF, Sexton DJ, Anderson DJ. Comparison of the burdens of hospital-onset, healthcare facility-associated Clostridium difficile Infection and of healthcare-associated infection due to methicillin-resistant Staphylococcus aureus in community hospitals. Infect Control Hosp Epidemiol. 2011;32(4):387-390. doi:10.1086/659156

2. McDonald LC, Gerding DN, Johnson S, et al. Clinical Practice Guidelines for Clostridium difficile Infection in Adults and Children: 2017 Update by the Infectious Diseases Society of America (IDSA) and Society for Healthcare Epidemiology of America (SHEA). Clin Infect Dis. 2018;66(7):e1-e48. doi:10.1093/cid/cix1085

3. Dubberke ER, Carling P, Carrico R, et al. Strategies to prevent Clostridium difficile infections in acute care hospitals: 2014 Update. Infect Control Hosp Epidemiol. 2014;35(6):628-645. doi:10.1086/676023

4. Biggest Threats and Data $\mid$ Antibiotic/Antimicrobial Resistance $\mid$ CDC. https://www.cdc.gov/DrugResistance/Biggest-Threats.html\#cdiff. Accessed March 10, 2020.

5. Rodrigues R, Barber GE, Ananthakrishnan AN. A Comprehensive Study of Costs Associated With Recurrent Clostridium difficile Infection. Infect Control Hosp Epidemiol. 2017;38(2):196-202. doi:10.1017/ice.2016.246

6. Lessa FC, Mu Y, Bamberg WM, et al. Burden of Clostridium difficile infection in the United States. N Engl J Med. 2015;372(9):825-834. doi:10.1056/NEJMoa1408913

7. Magill SS, Edwards JR, Bamberg W, et al. Multistate point-prevalence survey of health careassociated infections. $N$ Engl J Med. 2014;370(13):1198-1208. doi:10.1056/NEJMoa1306801

8. Gupta A, Khanna S. Community-acquired Clostridium difficile infection: an increasing public health threat. Infect Drug Resist. 2014;7:63-72. doi:10.2147/IDR.S46780

9. Li X, Wilson M, Nylander W, Smith T, Lynn M, Gunnar W. Analysis of Morbidity and Mortality Outcomes in Postoperative Clostridium difficile Infection in the Veterans Health Administration. JAMA Surg. 2016;151(4):314-322. doi:10.1001/jamasurg.2015.4263

10. Zacharioudakis IM, Zervou FN, Pliakos EE, Ziakas PD, Mylonakis E. Colonization with 
medRxiv preprint doi: https://doi.org/10.1101/2020.06.23.20138420; this version posted June 24, 2020. The copyright holder for this preprint (which was not certified by peer review) is the author/funder, who has granted medRxiv a license to display the preprint in perpetuity.

All rights reserved. No reuse allowed without permission.

toxinogenic C. difficile upon hospital admission, and risk of infection: a systematic review and meta-analysis. Am J Gastroenterol. 2015;110(3):381-390; quiz 391. doi:10.1038/ajg.2015.22

11. Branch-Elliman W, O’Brien W, Strymish J, Itani K, Wyatt C, Gupta K. Association of Duration and Type of Surgical Prophylaxis With Antimicrobial-Associated Adverse Events. JAMA Surg. April 2019. doi:10.1001/jamasurg.2019.0569

12. Starks I, Ayub G, Walley G, Orendi J, Roberts P, Maffulli N. Single-dose cefuroxime with gentamicin reduces Clostridium difficile-associated disease in hip-fracture patients. J Hosp Infect. 2008;70(1):21-26. doi:10.1016/j.jhin.2008.05.012

13. Hospital-Acquired Condition Reduction Program (HACRP) $\mid$ CMS. https://www.cms.gov/Medicare/Medicare-Fee-for-Service-Payment/AcuteInpatientPPS/HACReduction-Program. Accessed March 4, 2020.

14. Pépin J, Valiquette L, Alary M-E, et al. Clostridium difficile-associated diarrhea in a region of Quebec from 1991 to 2003: a changing pattern of disease severity. CMAJ. 2004;171(5):466-472. doi:10.1503/cmaj.1041104

15. Muto CA, Pokrywka M, Shutt K, et al. A large outbreak of Clostridium difficile-associated disease with an unexpected proportion of deaths and colectomies at a teaching hospital following increased fluoroquinolone use. Infect Control Hosp Epidemiol. 2005;26(3):273-280. doi:10.1086/502539

16. Oh J, Makar M, Fusco C, et al. A Generalizable, Data-Driven Approach to Predict Daily Risk of Clostridium difficile Infection at Two Large Academic Health Centers. Infect Control Hosp Epidemiol. 2018;39(4):425-433. doi:10.1017/ice.2018.16

17. Zilberberg MD, Reske K, Olsen M, Yan Y, Dubberke ER. Development and validation of a recurrent Clostridium difficile risk-prediction model. J Hosp Med. 2014;9(7):418-423. doi: $10.1002 / \mathrm{jhm} .2189$

18. LaBarbera FD, Nikiforov I, Parvathenani A, Pramil V, Gorrepati S. A prediction model for Clostridium difficile recurrence. J Community Hosp Intern Med Perspect. 2015;5(1):26033. doi:10.3402/jchimp.v5.26033

19. Bilimoria KY, Liu Y, Paruch JL, et al. Development and evaluation of the universal ACS NSQIP surgical risk calculator: a decision aid and informed consent tool for patients and surgeons. $\mathrm{J} \mathrm{Am}$ Coll Surg. 2013;217(5):833-42.e1. doi:10.1016/j.jamcollsurg.2013.07.385

20. Hall BL, Hamilton BH, Richards K, Bilimoria KY, Cohen ME, Ko CY. Does surgical quality improve in the American College of Surgeons National Surgical Quality Improvement Program: an evaluation of all participating hospitals. Ann Surg. 2009;250(3):363-376.

doi:10.1097/SLA.0b013e3181b4148f

21. Cohen ME, Ko CY, Bilimoria KY, et al. Optimizing ACS NSQIP modeling for evaluation of surgical quality and risk: patient risk adjustment, procedure mix adjustment, shrinkage adjustment, and surgical focus. J Am Coll Surg. 2013;217(2):336-46.e1. doi:10.1016/j.jamcollsurg.2013.02.027

22. Bovonratwet P, Bohl DD, Russo GS, Ondeck NT, Singh K, Grauer JN. Incidence, Risk Factors, and Impact of Clostridium difficile Colitis After Spine Surgery: An Analysis of a National Database. Spine. 2018;43(12):861-868. doi:10.1097/BRS.0000000000002430 
medRxiv preprint doi: https://doi.org/10.1101/2020.06.23.20138420; this version posted June 24, 2020. The copyright holder for this preprint (which was not certified by peer review) is the author/funder, who has granted medRxiv a license to display the preprint in perpetuity.

23. NSQIP 2017 user guide.

https://www.facs.org/ /media/files/quality\%20programs/nsqip/nsqip_puf_userguide_2017.ashx. Accessed May 15, 2019.

24. Hassan SA, Rahman RA, Huda N, Wan Bebakar WM, Lee YY. Hospital-acquired Clostridium difficile infection among patients with type 2 diabetes mellitus in acute medical wards. $J R$ Coll Physicians Edinb. 2013;43(2):103-107. doi:10.4997/JRCPE.2013.203

25. Pedregosa F, Varoquaux G, Gramfort A, et al. Scikit-learn: Machine Learning in Python. Journal of Machine Learning Research. 2011.

26. McFarland LV. Renewed interest in a difficult disease: Clostridium difficile infections-epidemiology and current treatment strategies. Curr Opin Gastroenterol. 2009;25(1):24-35. doi:10.1097/MOG.0b013e32831da7c4

27. Huang $\mathrm{H}, \mathrm{Wu} \mathrm{S}$, Chen $\mathrm{R}$, et al. Risk factors of Clostridium difficile infections among patients in a university hospital in Shanghai, China. Anaerobe. 2014;30:65-69. doi:10.1016/j.anaerobe.2014.08.015

28. Sartelli M, Di Bella S, McFarland LV, et al. 2019 update of the WSES guidelines for management of Clostridioides (Clostridium) difficile infection in surgical patients. World J Emerg Surg. 2019;14:8. doi:10.1186/s13017-019-0228-3

29. Turner MC, Behrens SL, Webster W, et al. Multidisciplinary Approach to Clostridium difficile Infection in Adult Surgical Patients. J Am Coll Surg. 2019;228(4):570-580. doi:10.1016/j.jamcollsurg.2018.12.045

30. Dial S, Alrasadi K, Manoukian C, Huang A, Menzies D. Risk of Clostridium difficile diarrhea among hospital inpatients prescribed proton pump inhibitors: cohort and case-control studies. CMAJ. 2004;171(1):33-38. doi:10.1503/cmaj.1040876

31. Pépin J, Saheb N, Coulombe M-A, et al. Emergence of fluoroquinolones as the predominant risk factor for Clostridium difficile-associated diarrhea: a cohort study during an epidemic in Quebec. Clin Infect Dis. 2005;41(9):1254-1260. doi:10.1086/496986

32. Carignan A, Poulin S, Martin P, et al. Efficacy of Secondary Prophylaxis With Vancomycin for Preventing Recurrent Clostridium difficile Infections. Am J Gastroenterol. 2016;111(12):18341840. doi:10.1038/ajg.2016.417

33. Abdelsattar ZM, Krapohl G, Alrahmani L, et al. Postoperative burden of hospital-acquired Clostridium difficile infection. Infect Control Hosp Epidemiol. 2015;36(1):40-46. doi:10.1017/ice.2014.8

34. Yong FA, Alvarado AM, Wang H, Tsai J, Estes NC. Appendectomy: a risk factor for colectomy in patients with Clostridium difficile. Am J Surg. 2015;209(3):532-535. doi:10.1016/j.amjsurg.2014.12.001

35. Tedesco FJ, Barton RW, Alpers DH. Clindamycin-associated colitis. A prospective study. Ann Intern Med. 1974;81(4):429-433. doi:10.7326/0003-4819-81-4-429

36. Hensgens MPM, Goorhuis A, Dekkers OM, Kuijper EJ. Time interval of increased risk for 
medRxiv preprint doi: https://doi.org/10.1101/2020.06.23.20138420; this version posted June 24, 2020. The copyright holder for this preprint (which was not certified by peer review) is the author/funder, who has granted medRxiv a license to display the preprint in perpetuity. All rights reserved. No reuse allowed without permission.

Clostridium difficile infection after exposure to antibiotics. $J$ Antimicrob Chemother. 2012;67(3):742-748. doi:10.1093/jac/dkr508

37. Johnson S, Samore MH, Farrow KA, et al. Epidemics of diarrhea caused by a clindamycin-resistant strain of Clostridium difficile in four hospitals. N Engl J Med. 1999;341(22):1645-1651. doi:10.1056/NEJM199911253412203

38. Satta G, Parekh S, Dabrowski H, Petkar H. Persisting variation in testing and reporting Clostridium difficile cases. J Infect Prev. 2015;16(5):217-220. doi:10.1177/1757177415580467 